\title{
PERANCANGAN APLIKASI OP-AMP DENGAN SOFTWARE GUI MATLAB
}

\author{
Triyono \\ Program Studi Teknik Elektro \\ Fakultas Teknik \\ Universitas Muhammadiyah Tangerang \\ Jl. Perintis Kemerdekaan I/33, Cikokol, Kota Tangerang \\ E-mail: lover_mu_1980@yahoo.co.id
}

\begin{abstract}
ABSTRAK
Operational Amplifier (OP-AMP) merupakan rangkaian penguat yang menjadi basis dari rangkaian audio dan video amplifier, filter, buffer (penyangga), komparator, oscilator dan rangkaian analog lainnya. Untuk meningkatkan pemahaman mahasiswa dalam merancang rangkaian OP-AMP dapat digunakan media pembelajaran berbantuan komputer. Matlab merupakan software yang digunakan dalam pembelajaran untuk melihat tanggapan beragam parameter dan masukan yang berbeda. Dari hasil penelitian didapatkan hasil yang cukup signifikan dalam peningkatan pemahaman mahasiswa dalam perancangan rangkaian OP-AMP.
\end{abstract}

Kata Kunci: OP-AMP, Matlab, Analog.

\section{PENDAHULUAN}

Operational Amplifier (OP-AMP) telah digunakan bertahun-tahun. Awalnya OPAMP dibentuk menggunakan sirkuit diskrit transistor, setelah perkembangan teknologi integrated ciruit (IC) telah merevolusi desain rangkaian analog. OP-AMP merupakan yang pertama sebuah IC analog, hal ini dikarenakan fungsinya yang sangat bermanfaat penggunaannya dalam beragam rangkaian.

Popularitas OP-AMP disebabkan oleh fleksibilitasnya. High-gain penguat DC yang memiliki input diferensial tegangan output adalah perbedaan tegangan antara dua input dikalikan dengan gain. Komponen pasif bisa digunakan untuk memberikan umpan balik, dan ini mengatur gain dan fungsi sirkuit OPAMP keseluruhan. Komponen umpan balik negatif pasif mengakibatkan linear respon, yaitu output sebanding dengan input. Umpan balik positif pasif hasil dalam switching atau osilasi. Komponen kadang-kadang aktif seperti transistor dan dioda digunakan dalam loop umpan balik untuk memberikan respon non-linear.

Permasalahan yang dihadapi dalam perancangan OP-AMP adalah mendapatkan nilai gain, output dan fungsi grafik rangkaian tersebut. Setelah didapatkan permasalahan selanjutnya adalah menganalisisnya apakah rangkaian yang dibuat berjalan dengan baik atau tidak. Seringkali mahasiswa mengalami kesulitan dalam menganalisis sistem, namun dengan bantuan software matlab proses analisis sistem menjadi jauh lebih mudah dan cepat sehingga akan memudahkan dalam proses pembelajaran terutama dalam perancangan sistem dengan menggunakan rangkaian OP-AMP.

\section{OPERATIONAL AMPLIFIER}

Pada OP-AMP terdapat satu terminal keluaran, dan dua terminal masukan. Terminal masukan yang diberi tanda (-) dinamakan terminal masukan pembalik (inverting), sedangkan terminal masukan yang diberi (+) 
dinamakan terminal masukan bukan pembalik (noninverting). Berikut merupakan gambar simbol OP-AMP.

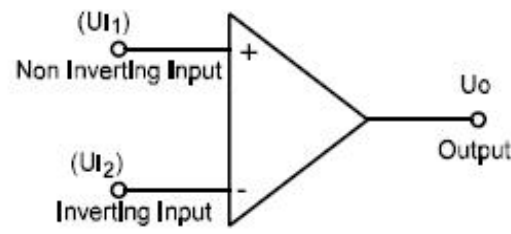

Gambar 1. Simbol OP-AMP

Jika input OP-AMP diberi tegangan searah dengan input Non Inverting $(+)$ lebih besar dari pada input inverting (-), maka pada output OP-AMP akan positif (+). Sebaliknya jika input Non Inverting (+) lebih kecil dari pada input inverting (-), maka output OP-AMP akan negatif (-).

Tabel 1. Perbedaan parameter beberapa OP-AMP

\begin{tabular}{|l|l|l|l|l|}
\hline Parameter & Ideal & LM741 & LF347 & LM318 \\
\hline Open-loop Gain $\left(\mathrm{A}_{\text {oL }}\right)$ & $\infty$ & $2.10^{5}$ & $10^{5}$ & $2.10^{5}$ \\
\hline Input Resistance $\left(\mathrm{R}_{\text {in }}\right)$ & $\infty \Omega$ & $2 \mathrm{M} \Omega$ & $10^{12} \Omega$ & $3 \mathrm{M} \Omega$ \\
\hline Output Resistance $\left(\mathrm{R}_{\mathrm{o}}\right)$ & $0 \Omega$ & $75 \Omega$ & $75 \Omega$ & $75 \Omega$ \\
\hline Gain Bandwidth Product & $\infty \mathrm{Hz}$ & $1 \mathrm{MHz}$ & $4 \mathrm{MHz}$ & $15 \mathrm{MHz}$ \\
\hline CMRR & $\infty$ & $90 \mathrm{~dB}$ & $100 \mathrm{~dB}$ & $100 \mathrm{~dB}$ \\
\hline
\end{tabular}

\subsection{Penguat Inverting}

Rangkaian dasar penguat inverting adalah seperti yang ditunjukkan pada gambar 2, dimana sinyal masukannya dibuat melalui input inverting.

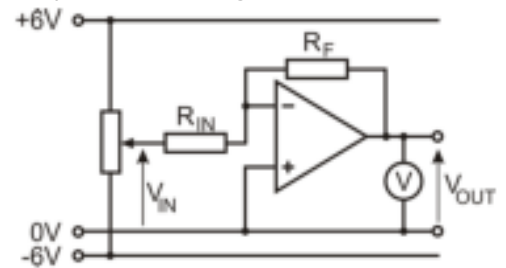

Gambar 2. Penguat Inverting Input non-inverting pada rangkaian

ini dihubungkan ke ground, atau $\mathrm{V}^{+}=0$. Karena nilainya $=0$, namun tidak terhubung langsung ke ground, input op-amp $\mathrm{V}^{-}$pada rangkaian ini dinamakan virtual ground. Dengan demikian dapat dihitung tegangan jepit pada $R_{\text {in }}$ adalah $\mathrm{V}_{\text {in }}-\mathrm{V}^{-}=\mathrm{V}_{\text {in }}$ dan tegangan jepit pada resistor $\mathrm{Rf}$ adalah $\mathrm{V}_{\text {out }}$
$-v^{-}=V_{\text {out. }}$ Kemudian di ketahui bahwa: iin

+ iout $=\mathrm{i}^{-}=0$, arus masukan op-amp adalah 0 . Maka: iin + i out $_{\text {oun }}=V_{\text {in }} / R_{\text {in }}+V_{\text {out }} / R_{f}=0$, Selanjutnya $V_{\text {out }} / R_{f}=-V_{\text {in }} / R_{\text {in }}$ atau $V_{\text {out }} / \mathrm{V}_{\text {in }}=-\mathrm{Rf}_{\mathrm{f}} / \mathrm{Rin}$. Jika penguatan $\mathrm{G}$ didefenisikan sebagai perbandingan tegangan keluaran terhadap tegangan masukan, maka dapat ditulis $\mathrm{G}=\mathrm{V}_{\mathrm{out}} / \mathrm{Rf}=\mathrm{-}$ $V_{\text {in }} / R_{\text {in }}$.

\subsection{Peenguat Non-Inverting}

Rangkaian dasar penguat inverting adalah seperti yang ditunjukkan pada gambar 3, dimana sinyal masukannya dibuat melalui input non-inverting. Dengan demikian tegangan keluaran rangkaian ini akan satu fasa dengan tegangan inputnya.

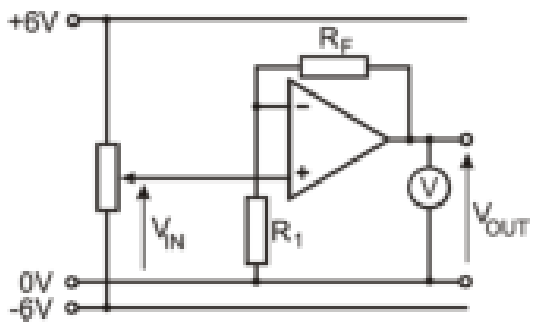

Gambar 3. Penguat Non-Inverting

Jika: $\mathrm{V}_{\text {in }}=\mathrm{V}^{+}$dan $\mathrm{V}^{+}=\mathrm{V}^{-}=\mathrm{V}_{\text {in }}$. Dari sini ketahui tegangan jepit pada $\mathrm{Rf}$ adalah $V_{\text {out }}$ $-\mathrm{V}^{-}=\mathrm{V}_{\text {out }}-\mathrm{V}_{\text {in }}$, atau iout $=\left(\mathrm{V}_{\text {out }}-\mathrm{V}_{\text {in }}\right) / \mathrm{Rf}$. Lalu tegangan jepit pada $R_{1}$ adalah $V^{-}=V_{i n}$, yang berarti arus $i R_{1}=V_{i n} / R_{1}$. Hukum kirchoff pada titik input inverting bahwa iout $+\mathrm{i}(-)=\mathrm{iR} 1$ serta $\mathrm{i}(-)=0$ dan jika disubsitusi ke rumus yang sebelumnya, maka diperoleh iout $=i R 1$ dan Jika ditulis dengan tegangan jepit masing-masing maka diperoleh ( $V_{\text {out }}$ $\left.V_{\text {in }}\right) / R f=V_{\text {in }} / R 1$ yang kemudian dapat disederhanakan menjadi: $V_{\text {out }}=V_{\text {in }}(1+$ $\mathrm{Rf} / \mathrm{R} 1)$. Jika penguatan $\mathrm{G}$ adalah perbandingan tegangan keluaran terhadap tegangan masukan, maka didapat penguatan op-amp non-inverting: $\mathrm{G}=\mathrm{V}_{\text {out }} / \mathrm{V}_{\text {in }}=(1+$ $\mathrm{Rf} / \mathrm{R} 1)$. 


\subsection{Voltage Follower}

Rangkaian dasar penguat voltage follower adalah seperti yang ditunjukkan pada gambar 4, rangkaian voltage follower berguna untuk meningkat arus tanpa mengubah tegangannya. Digunakan untuk mengubah sinyal berimpedansi tinggi menjadi sinyal berimpedansi rendah yang kokoh (robust). Gain voltage follower 1.

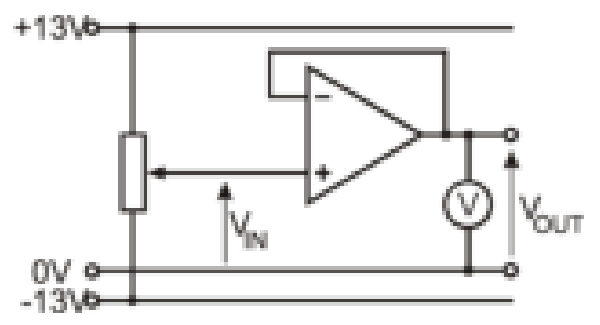

Gambar 4. Voltage Follower

$\mathrm{R}$ in adalah tahananan yang sangat besar dan $\mathrm{R}$ adalah tahananan yang sangat kecil. Kembali ke persamaan awal saat Vout sama dengan V1 maka persamaan awal menjadi:

$$
V_{\text {out }}=A\left(V^{+}-V_{-} \text {out }\right)
$$

sehingga bila Vout yang dicari maka persamaan menjadi:

$$
V_{\text {out }}=\frac{A V^{+}}{1+A} \approx V^{+}
$$

\subsection{Summing Amplifier}

Rangkaian dasar penguat summing amplifier adalah seperti yang ditunjukkan pada gambar 5, summing amplifier digunakan sebagai penjumlah tegangan. Summing amplifier dapat digunakan untuk menjumlah tegangan dari beberapa sumber yang memiliki arus yang berbeda.

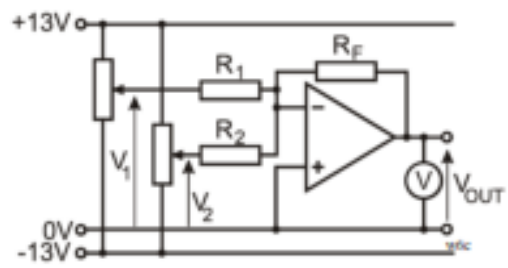

Gambar 5. Summing Amplifier

Persamaan tegangan keluaran ditentukan sebagai berikut:

$$
V_{\text {out }}=-\left(\frac{R_{f}}{R_{1}} V_{1}+\frac{R_{f}}{R_{2}} V_{2}\right)
$$

\subsection{Differential Amplifier}

Rangkaian dasar penguat differential amplifier adalah seperti yang ditunjukkan pada gambar 6, differential amplifier merupakan amplifier yang digunakan untuk mencari selisih tegangan dari dua sinyal yang masuk.

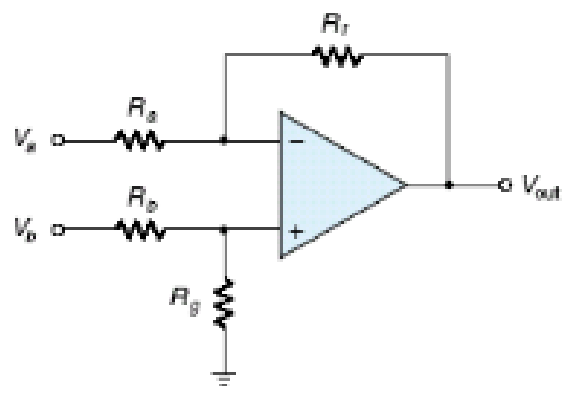

Gambar 5. Differential Amplifier

Persamaan tegangan output-nya dinyatakan sebagai berikut:

$$
V_{\text {out }}=\frac{R_{f}}{R_{a}}\left(V_{b}-V_{a}\right)
$$

Tegangan output merupakan tegangan tunggal yang mengacu pada ground biasanya disebut single ended voltage. 


\section{Metodologi Penelitian}

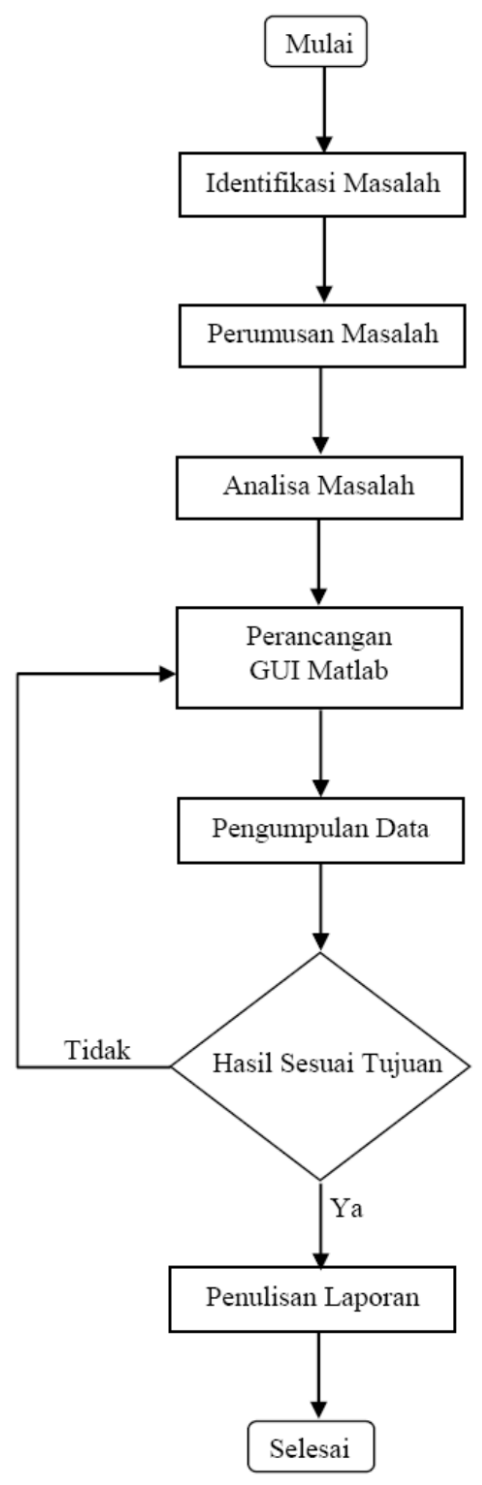

\section{Hasil}

Rancangan aplikasi GUI Op-Amp diujicobakan kepada mahasiswa dibandingkan dengan menggunakan metode praktikum, metode perhitungan manual. Setelah dilakukan tindakan kelas terjadi peningkatan yang cukup signifikan terhadap pemahaman dan ketertarikan mahasiswa dalam mempelajari materi analog berbasis operational amplifier pada mata kuliah Teknik Analog dan Digital. Hal ini menunjukkan bahwa penggunaan GUI matlan sangat membantu dosen dalam menyampaikan materi operational amplifier kepada mahasiswa. Penggunaan Matlab tidak hanya pada operational amplifier semata, tetapi dapat dikembangkan pada materi-materi yang berhubungan dengan kendali maupun sinyal.

\section{Kesimpulan}

Berdasarkan hasil pembahasan yang dilakukan dapat diambil beberapa kesimpulan sebagai berikut:

a. Pengembangan GUI MATLAB untuk aplikasi Op-Amp sangat membantu mahasiswa dalam memahami materi secara keseluruhan.

b. Perancangan GUI MATLAB untuk aplikasi Op-Amp sangat memudahkan untuk mendapatkan hasil perhitungan yang tepat.

c. Penerimaan materi GUI MATLAB untuk aplikasi Op-Amp lebih baik dibandingkan dengan metode pembelajaran konvensional.

d. Pengembangan metode pembelajaran kreatif, inovatif dan terbarukan perlu terus ditingkatkan untuk meningkatkan pemahaman dan prestasi mahasiswa yang lebih baik dalam mempelajari materi.

\section{DAFTAR PUSTAKA}

Annonymous. 2010. Loctronics Simplifying Electricity Operational Amplifier. Matrix Multimedia

Attia, John Okyere. 1999. Electronics and circuit analysis using MATLAB. CRC Press.

Clayton, George and Winder, Steve. 2003. Operational Amplifiers Fifth Edition. Newnes.

Jung, Walt. ed. 2005. Op Amp Applications Handbook. Newnes 


\section{Lampiran \\ Perancangan Aplikasi OP-AMP Dengan Software GUI Matlab}

\section{Inverting Amplifier}

kasus 1

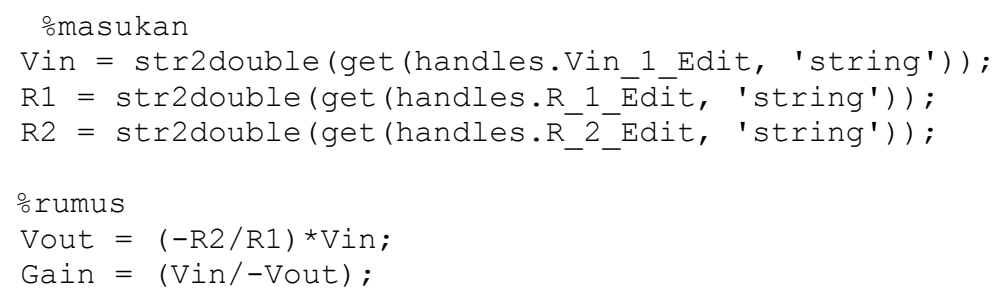




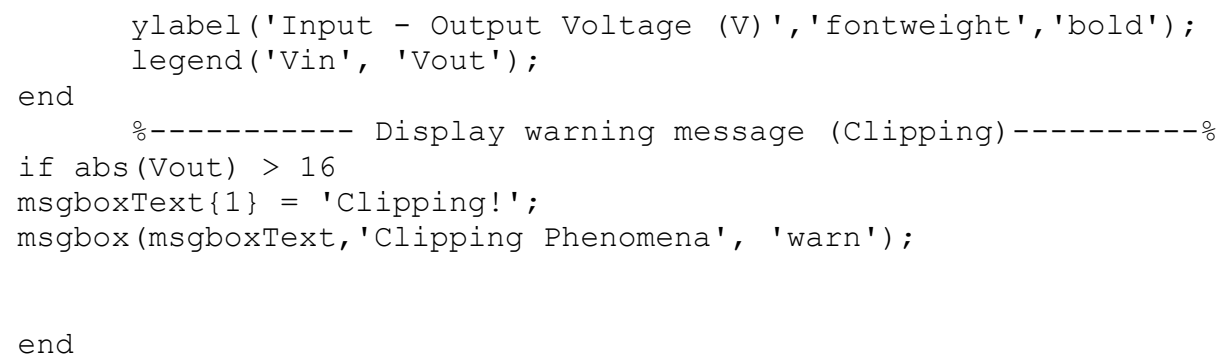

\section{Non-Inverting Amplifier}

\section{kasus 2}

omasukan

Vin = str2double (get (handles.Vin_1_Edit, 'string'));
R1 = str2double (get (handles.R 1 Edit, 'string'));

R2 = str2double (get (handles.R_2_Edit, 'string'));

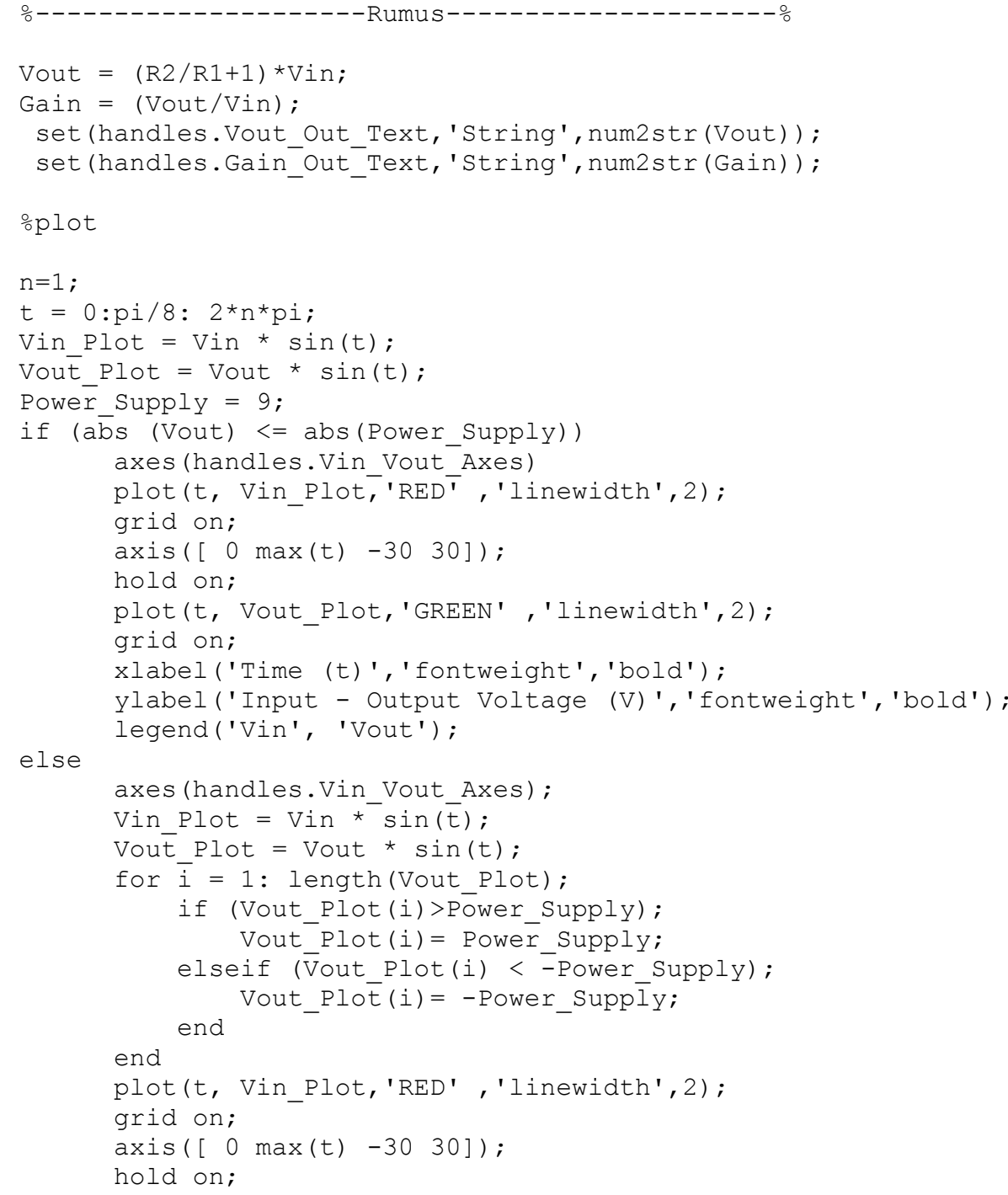




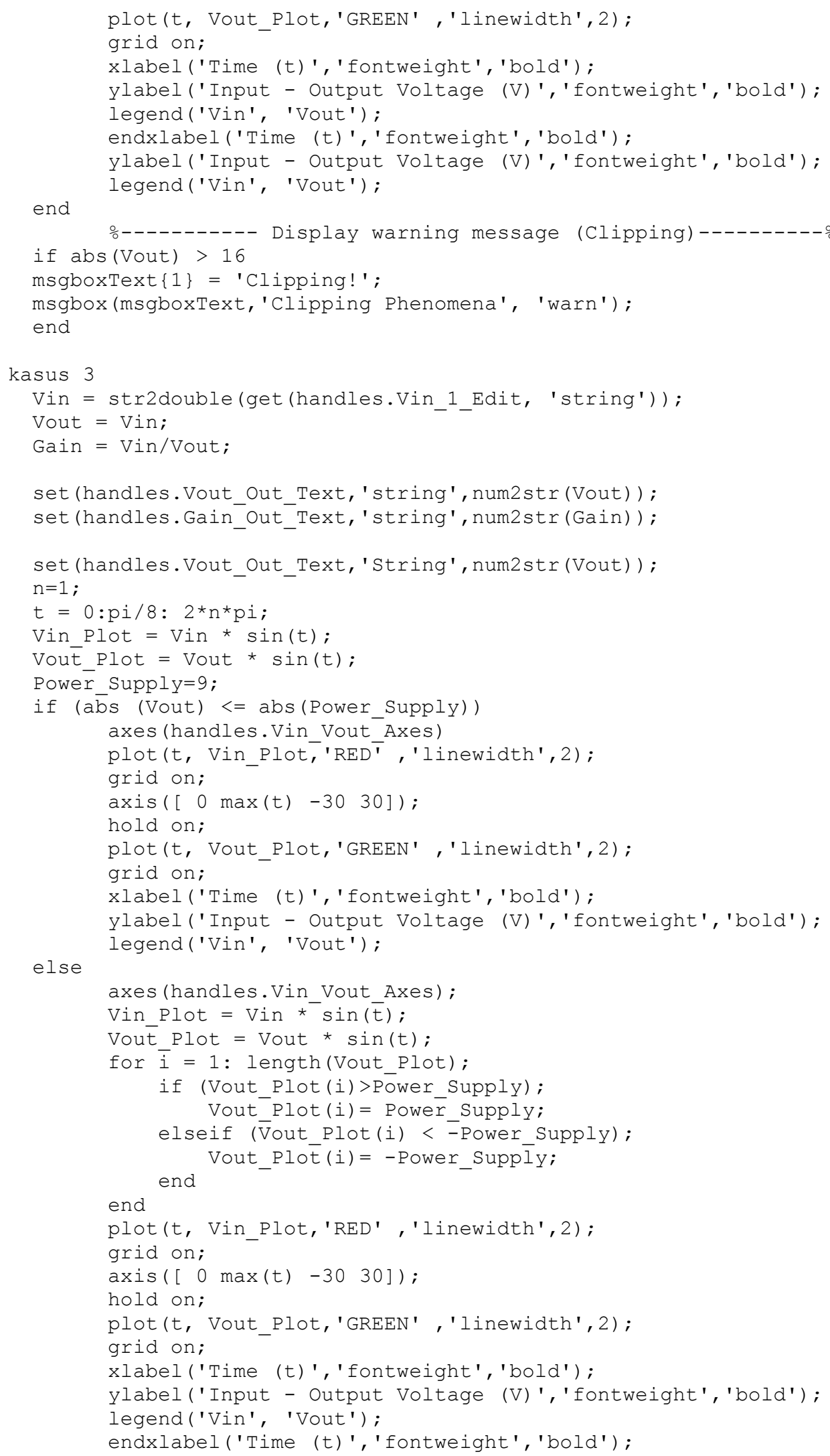




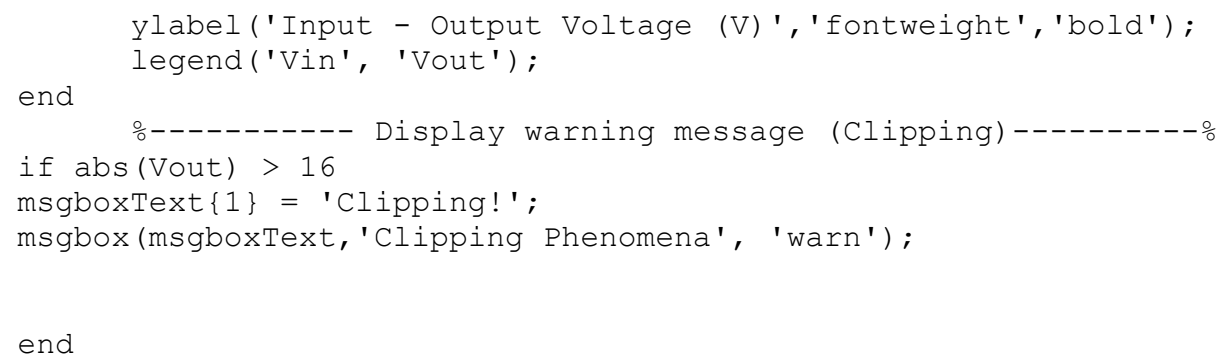

\section{Summing Amplifier}

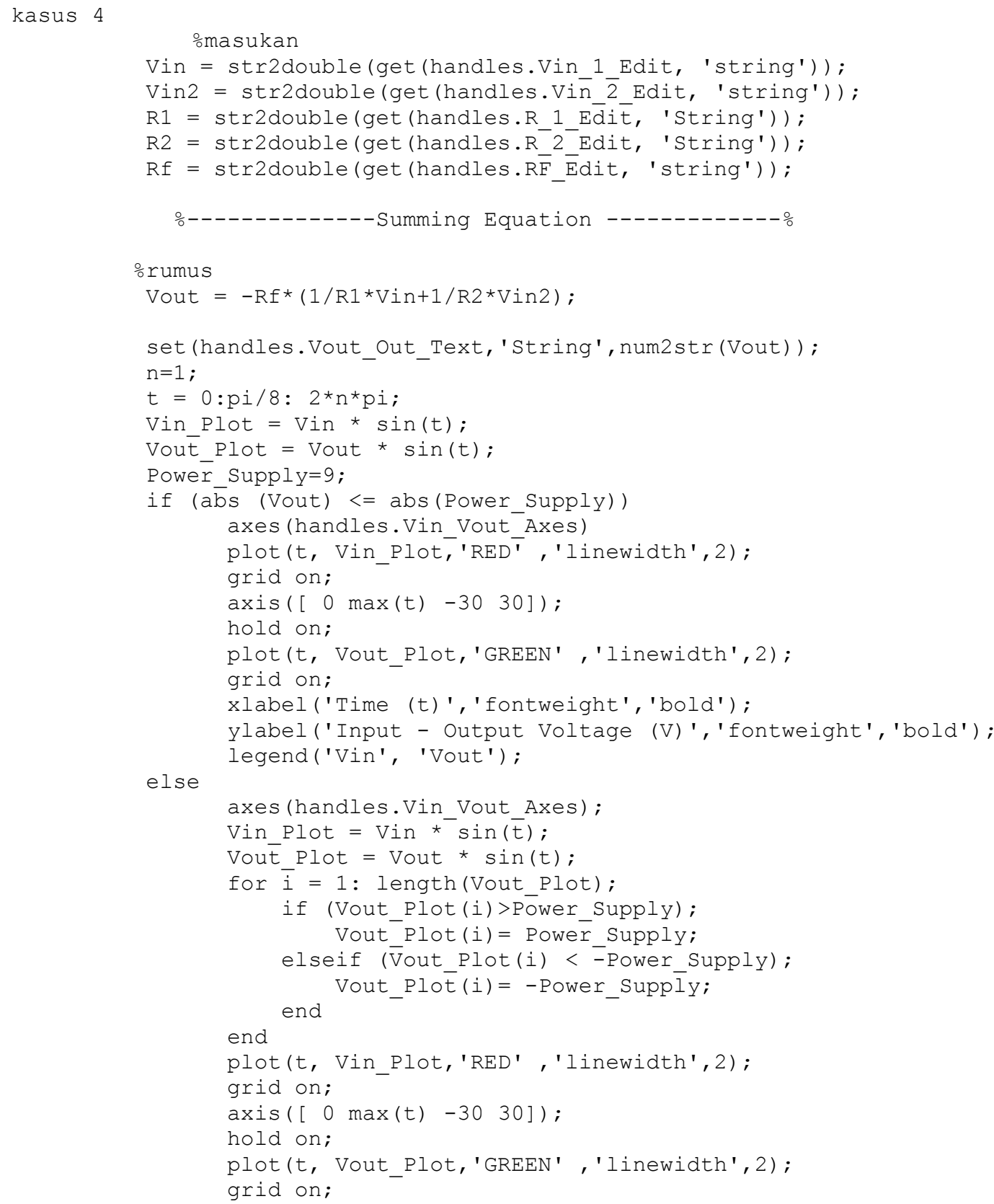




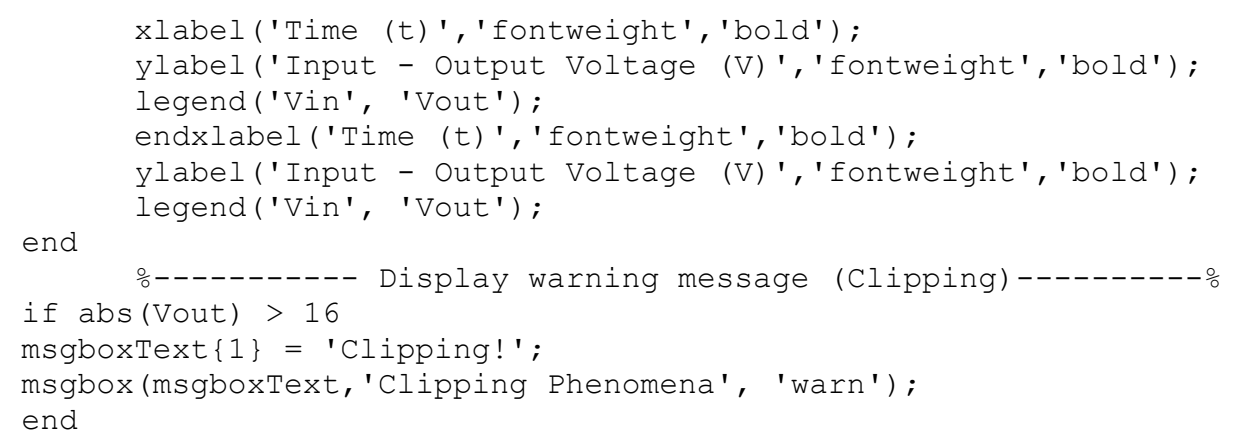

\section{Differential Amplifier}

kasus 5

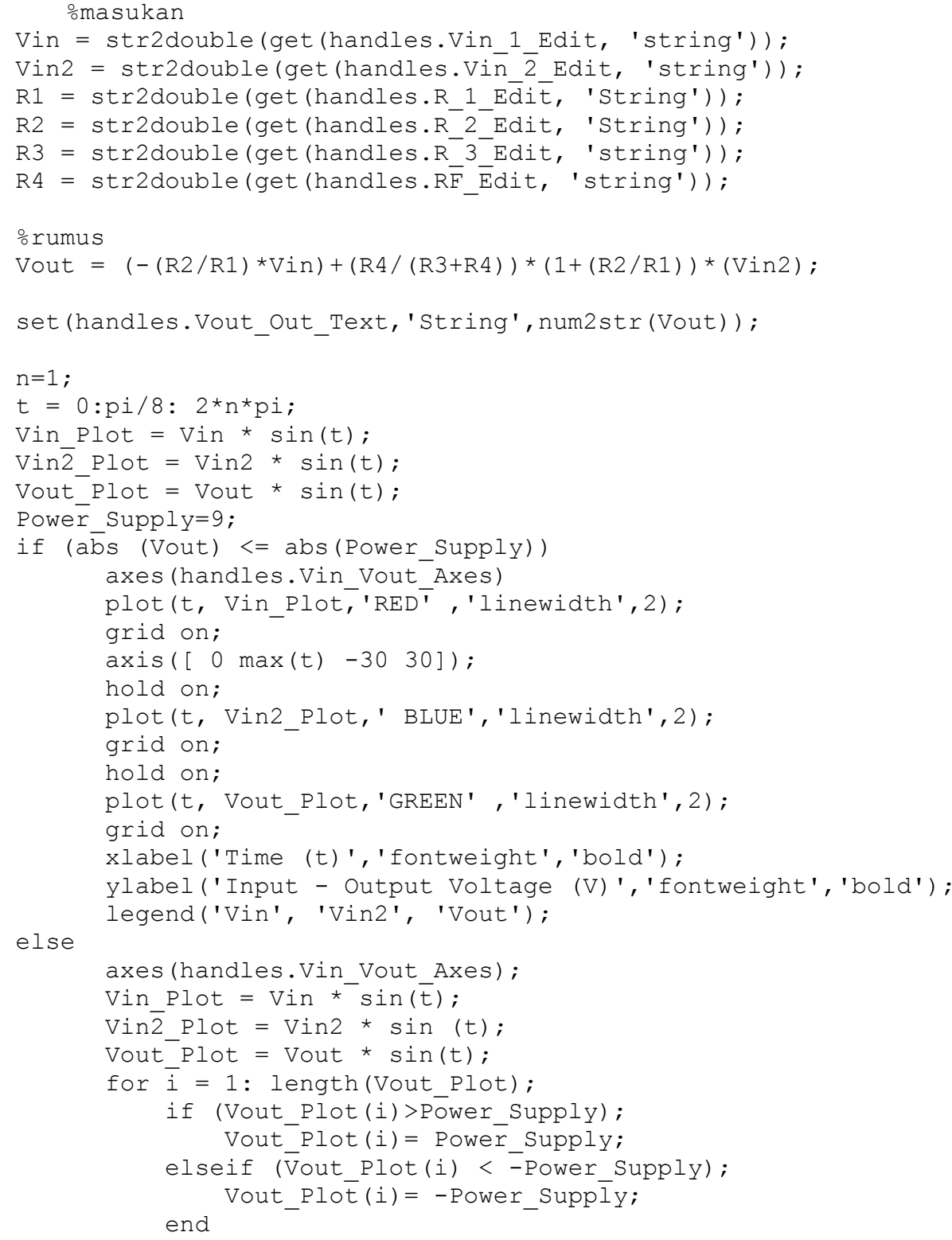




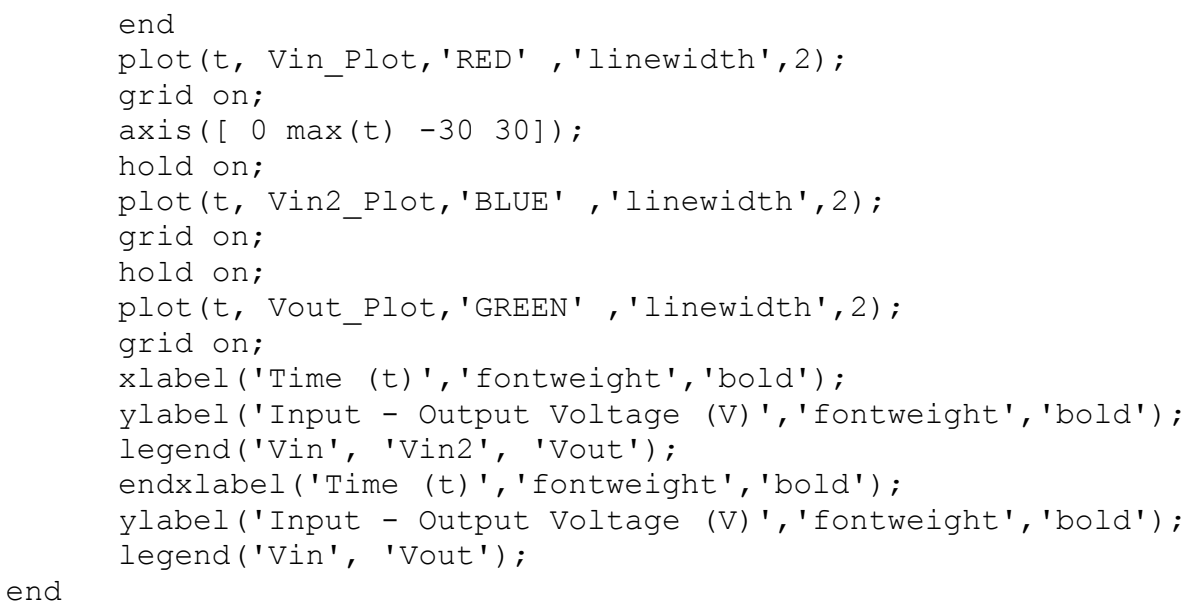

